ROCZNIKI HUMANISTYCZNE

Volume 67, issue $4-2019$

SELECTED PAPERS IN ENGLISH

DOI: http://dx.doi.org/10.18290/rh.2019.67.4-6en

\title{
TWO SISTERS: THE SCULPTOR HANNA NAŁKOWSKA IN THE LIGHT OF ZOFIA NAŁKOWSKA’S NOVEL WĘŻE I RÓŻE
}

Of the two daughters of Wacław Nałkowski and Anna Nałkowska, only their writing daughter Zofia is widely known. The figure and artistic output of the other daughter, the sculptor Hanna Nałkowska, is somewhat overshadowed by the elder sister. The author of several dozen sculpture pieces, Hanna Nałkowska, was born in Warsaw in 1888 and died there in $1970 .{ }^{1}$ Raised among writers, she was the only one in the family to choose a profession related to visual arts. She was involved in sculpture projects all her life and, interestingly, was only the second generation of women professionally involved in art. Her creative imperative was

Magdalena Kasa, MA - a PhD student at the Institute of Arts, the Polish Academy of Sciences, ul. Długa 26/28,00-238 Warszawa; e-mail: magdalena.kasa@gmail.com

The Polish version of the article was published in Roczniki Humanistyczne vol. 65, issue 4 (2017).

${ }^{1}$ Hanna Nałkowska was educated at Emilia Pankiewiczówna's finishing schools; she attended drawing, painting and decoration classes at a school for women run by Maria Zaremba-Słupska and a sculpture course run by Teodor Skonieczny at the Museum of Industry and Crafts in Warsaw. In 1909-1910 she studied at the School of Fine Arts as a student of Xawery Dunikowski. She returned to the same establishment again in the years 1915-1917 and continued her education under the supervision of Edward Wittig. In the late 1930s, she left for Paris to attend courses led by Joseph Bernard, Charles Despiau, and Marcel Gimond. Nałkowska exhibited three times in Warsaw (1922, 1931, 1963 ) as well as staging exhibitions across the country (including in Warsaw, Łódź, Opole, Lublin) and abroad (the Salon in Paris, the Paris World's Fair in 1937), the New York World's Fair in 1939). Nałkowska excelled in portrait sculpture; she authored the images of Zofia and Wacław Nałkowski, Stefan Żeromski, Walerian Łukasiński, Jan Brzechwa, Gustaw Orlicz-Dreszer, Władysław Tatarkiewicz, and Józef Piłsudski. See Magdalena KASA, "Rzeźbię, co koń wyskoczy. O twórczości Hanny Nałkowskiej," Aspiracje 3 (2015): 36-41. 
strong enough to make her reach beyond the existing state of affairs. It was not only a derivative of her individual traits, but it went deeper and stemmed from a desire for freedom of action and to cross the existing socio-cultural boundaries, including family traditions. ${ }^{2}$ Those researching Hanna Nałkowska's art should not ignore her sister's literary output. The novel Węże $i$ róże $e^{3}$ [Snakes and Roses] deserves special attention as the only piece in Nałkowska's literatury output where she addresses the subject of art and portrays a character of an artist, Ernestyna Śniadowiczówna. ${ }^{4}$ In the following part of the article, I am going to demonstrate that the character was modelled on the sculptor Hanna Nałkowska.

The novel Węże $i$ róże was completed at a special moment: after the death of the author's father, Wacław Nałkowski, who died on 29 January 1911. For the following four months, Zofia Nałkowska suspended her diary entries and literary activity. The new novel broke the silence. The outline of the book was ready in the second half of 1911, and it was released a year and a half later. ${ }^{5}$ And although Nałkowska had initially approached the book with tremendous optimism, ${ }^{6}$ arising difficulties discouraged her from continuing the work on a regular basis. She became reluctant to write and took a long time to make progress.

\footnotetext{
${ }^{2}$ Roman ZAWADZKI, "Czym jest i czym może być portret psychologiczny,” in Portrety psychologiczne, ed. Roman Zawadzki (Warszawa: Wydawnictwo Uniwersytetu Warszawskiego, 2010), 55.

${ }^{3}$ Zofia NaŁKOWSKA, Węże i róże (Warszawa: Czytelnik, 1977).

${ }^{4}$ Some ideas from Węże $i$ róże were discussed by: Dagmara WACHNA, "Sposoby widzenia sztuki w 'Wężach i różach' Zofii Nałkowskiej oraz 'Przygodzie w nieznanym kraju' Anieli Gruszeckiej," Ruch Literacki 5 (2001): 537-554; Hanna KIRCHNER, "Modernistyczna młodość Zofii Nałkowskiej," Pamiętnik Literacki 1 (1968): 67-109; Włodzimierz WóJcıK, Zofia Nałkowska (Warszawa: Wiedza Powszechna, 1973), 55-82; Dorota KIELAK, Figury kryzysu. Rzeźba w młodopolskiej powieści o artyście (Warszawa: Wydawnictwo UKSW, 2007), 380-382; Magdalena REMBOwSKA-PŁÓCIENNIK, "Family Nausea: Attitudes towards Family Values in Zofia Nałkowska's 'Snakes and Roses' and 'The Impatient Ones'," in Gender and Sexuality in Ethical Context, ed. Ursula PHILliPs, Knut A. GRIMSTAD (Bergen: University of Bergen, 2005), 155-177; Bożena UMIŃSKA, “Zofia Nałkowska, 'Węże i róże.' Odmieniec," in EADEM, Postać z cieniem. Portrety Żydówek w polskiej literaturze od połowy XIX wieku do 1939 roku (Warszawa: Sic!, 2011), 187-208; Marta ToMczoK (Cuber), "Krew i dymy holokaustów.' 'Węże i róże' wobec kwestii żydowskiej w twórczości Zofii Nałkowskiej," in Granice Zofii Nałkowskiej, ed. Agata Zawiszewska (Warszawa: Uniwerstyet Szczeciński, 2014), 265-284.

${ }^{5}$ The book was published in parts. "I am constantly meditating and making notes to my new novel." (Zofia NAŁKOWSKA, Dzienniki 1909-1917 (Warszawa: Czytelnik, 1976), 196, entry dated 08.09.1911).

6 "I can't wait to start writing this new novel that I am in love with" (ibidem, 204, entry dated 01.12.1911).
} 
At that time, the author had to look after her bereaved mother, who had locked herself in "a terrible world of memories that frighten her," and her sister who was having a hard time after father's departure. Before the book was out, Hanna had fallen ill many times, as we learn from Nałkowska's memoires, Dziennik. ${ }^{8}$ At that time, the writer divorced her husband Leon Rygier and left Warsaw to return to Górki to reunite with her mother and sister. ${ }^{9}$ There is where she penned the subsequent parts of her book. She sought strength and consolation in close relatives, which surfaces in her Dziennik and very emotional entries of the time, "I am calm and safe only when we are together, at least the three of us." "... that thing has been going on for a month, and it has made me abandon all dreams and hopes. It's Hanka's disease, pleurisy. ...It gives me some irretrievable and lethal joy to relieve her by pondering to her nice and playful whims, and yet, out of this whole world, I only have this house in Gorki and the two of them." "...my only support in all this despair and destruction is my family. I love them both with all the feelings I have."12 These are Zofia's most personal confessions on her younger sister. That hard time in the lives of the three lonely women ${ }^{13}$ was the period in which the writer clearly alluded to her sister's artistic work for the first time. By that time, Hanna had already completed the Warsaw School of Fine Arts and had debuted in the artistic world. It was a period of solidification of her creative personality. When Zofia was working on Węże i róże, Hanna staged her first exhibition (Img. 1, 2, 3) ${ }^{14}$ It is possible that Helena's

\footnotetext{
${ }^{7}$ Ibidem, 203 (entry dated 25.11.1911).

${ }^{8}$ This is seen in these entries: "Hanka sick again," 25.09.1912; "Hanka is feverish again," 4.01.1913; "Hanka has been ill for so long. Doctors keep coming; she gets chloroform; after that, only two weeks apart, she gets lymphangitis in her hand...loneliness in the face of all the horror of her suffering, helplessness and financial setbacks," 16.03.1913; "Hanka is worse again and immediately everything falls down to the bottom of life," 27.03.1913; "My sister is also sick," 06.1913.

${ }^{9}$ Nałkowskis' house built near Wołomin in 1895 . In the 1930 s, due to financial instability caused by the cost of maintenance of the Górki property, the Nałkowskis were forced to sell the house and land. Today it houses the Museum of Zofia and Wacław Nałkowski.

${ }^{10}$ Dzienniki, 203 (entry dated 25.11.1911).

${ }^{11}$ Ibidem, 220 (entry dated 09.06.1912).

${ }^{12}$ Ibidem, 261 (entry dated 29.04.1913).

${ }^{13}$ This is how Nałkowska described the threesome, "our threesome lives here alone, ascetically, bizarrely - as if in a depressed, foreign book" (ibidem, 282, entry dated 12.11.1913).

${ }^{14}$ In 1913 she exhibited Helenka at the Spring Salon, see Salon Wiosenny artystów warszawskich: maj-czerwiec 1913 (Warszawa: Towarzystwo Zachęty Sztuk Pięknych, 1913). At the Annual Exhibition
} 
activity made Zofia believe that her sister's endeavours are not a short-lived fancy but a mature and anything but an accidental choice. During Hanna's illness, Zofia noted in her Dziennik, "With the greatest sense of bitterness, before going to bed, I moisten and wrap her unfinished sculptures with wet cloth to prevent them from drying and cracking." 15 In a letter to a friend, she adores her sister's achievements, "before her illness, however, her completed sculpture was cast, and even Dunikowski and Kuna came to see it, and, although representing different streams of art, they simply could not find words to express their appreciation." ${ }^{16}$ Zofia meant the sculpture Helenka, which two months later became the main theme of her new entry in Dziennik, "there is a great celebration in the house because my sister's first sculpture has been accepted to be displayed at the Spring Salon; its photo is in the catalogue" (Img. 1). ${ }^{17}$

Nałkowska repeatedly emphasized in Dziennik that all her novels were bringing together and were building on her personal experience. In 1910 she described herself as "a realist in depicting the events of mental life. I do not invent anything, I do not imagine things, I just put together the details of my own experiences to achieve a pattern." 18 Her literary technique never really evolved. Thirty years later, she pointed out, "my only reason for writing is an enduring desire to make a stop in life, to save it from loss or destruction. Because it is the most challenging to describe events or other people's affairs, it turns out that, ultimately, I am only documenting myself." 19 Her confessions are key for the analysis of Węże $i$ róze as they help explain the origin of many threads in the novel, as Grażyna Borkowska put it, "whatever you create, you create yourself. Whatever you reveal, you reveal yourself. Writing (creating) women are stuck inside a framed discourse, unable to distance themselves, break the bonds with the text, unable to cover or conceal themselves and escape." ${ }^{20}$ Before writing the novel, Nałkowska had made several important

in December the same year, she showed Zofia's Portrait and A Portrait of Mrs. Z.G., see Salon 1913: grudzień-styczeń (Warszawa: Zakłady Graficzne B. Wierzbicki i S-ka, 1913).

${ }^{15}$ Dzienniki, 220 (entry dated 09.06.1912).

${ }^{16}$ A letter to Zofia Villaume dated 16.03.1913, ibidem, 251-252.

${ }^{17}$ Ibidem, 262-263 (entry dated 09.05.1913).

${ }^{18}$ Ibidem, 162 (entry dated 14.10.1910).

${ }^{19}$ Zofia NaŁKowsKa, Dzienniki 1939-1944 (Warszawa: Czytelnik, 1996), 423.

${ }^{20}$ Grażyna BoRkowsKA, Cudzoziemki. Studia o polskiej prozie kobiecej (Warszawa: Instytut Badań Literackich PAN, 1996), 13. 
journeys. ${ }^{21}$ In 1909, during her stay in Kraków, she was accommodated at Flora Epstein who helped her associated with the Jewish financial circles. Based on that experience, Nałkowska depicted the fictional Oliwny family in her novel. ${ }^{22}$ Shortly afterwards, Flora Epstein invited Nałkowska to join her on a trip to Italy. By visiting Italian museums and palaces, the writer gained a first-hand experience of the Italian culture. This enabled her later on to provide competent and detail-rich descriptions of the works of art or historical figures mentioned in the novel. During her trip to Vienna, Nałkowska saw Ginevra de' Benci, a portrait painting by Leonardo da Vinci. Ginevra's beauty inspired Nałkowska to portray Marusia, the main protagonist of her novel. ${ }^{23}$ The plot of the novel and the story of the protagonists revolve around the Oliwny family. The central figure among them is Marusia, her unfaithful husband, Dr Orych, calculating Modesta, Raissa Benoni - Ernestyna's disciple, and Mr Czarostański, a bachelor and womanizer. The key theme of the novel is a tragic story of Marusia. It is in fact a tale of developing insanity that leads the main character into killing her underdeveloped daughter Muma ${ }^{24}$ and, in the end, a suicide. ${ }^{25}$ The most important for the story, however, is the story of another protagonist, Ernestyna Śniadewiczówna, a young amateur artist who, having returned from a trip to Italy, undertakes to become a tutor of a teenager, Raissa Benoni. In fact, Ernie (this is how she is called throughout the novel) is a figure that the reader knows little about. Nałkowska gave her a secondary, yet intriguing role in the story. Her appearance makes Węże i róże lose its compositional compactness. Ernestyna watches the course of events and operates outside the mainstream plot. This may imply

\footnotetext{
${ }^{21}$ In less than four years, Nałkowska visited Venice, Florence, Rome, Vienna, Prague, and Dresden.

22 "I am exploring the bizarre spheres of the Jewish high finance. It is a vast world of various phenomena." (Dzienniki 1909-1917, 103-104, entry dated 12.11.1909); cf. Hanna KIRCHNER, "Powieść poetycka," in EADEM Natkowska albo życie pisane (Warszawa: Wydawnictwo W.A.B., 2011), 131-148.

23 "Ginevra de Benci has just been born for me; she is always so ugly on reproductions. Marusia from Weże $i$ róże must have such a face and such eyes, sad and convex, and such hopelessly ascetic lips" (Dzienniki 1909-1917, 275, entry dated 28.08.1913).

${ }^{24}$ It is worth noting that during Zofia's work on Węże $i$ róże, to ease their financial condition, the Nałkowskis were renting rooms in the Górki house. "From tomorrow on, our ground floor apartment is taken over by an institute with twelve underdeveloped children" (ibidem, 221, entry dated 09.06.1912).

${ }^{25}$ Nałkowska often toyed with the idea of madness and mental instability in her Dziennik. It became particularly visible in her reflections on Maria Komornicka, ibidem, 308 (entry dated 03.03.1914).
} 
a certain resemblance to Hanna Nałkowska, a withdrawn artist, living by the side and overshadowed by her elder sister. In Notatki o Zofii Natkowskiej, there is a following passage, "Zofia lives with her sister, Hania, a sculptor. Hania, despite her reputation as a sculptor, despite exhibitions, flattering critics and awards, is important as Zofia's sister in the first place." ${ }^{26}$ The text is dated $1945,{ }^{27}$ i.e. when the artist was already 57 years old, of which several dozen of years she had devoted to sculpture. This sentence perfectly demonstrates a thirdparty view of the relationship between the sisters. It is worth noting that Hanna's "background" role was in a sense "affixed" to her personality. A friend of the Nałkowski sisters, Halina Dąbrowolska, recalled that despite Hanna had resided in the house on a regular basis, "her presence was fragmentary: she appeared only for meals in the dining room." ${ }^{28}$ Erna's character in the novel is designed in a similar way, although no researcher has noticed that coincidence yet. Some identified the main protagonist with the author. Dagmara Wachna assumes that Nałkowska created her private ideal woman: a beautiful, intelligent and unreachable being, taking her partners not too seriously and stable in her feelings. ${ }^{29}$ In contrast, Hanna Kirchner recognizes Ernestyna as the author's porte-parole. As she put it, "this quasi character actually exists only to keep a record of the writer's 'thoughts' loosely, or even not at all, related to the novel; she plays an insignificant role plot-wise." 30

Węże $i$ róże abounds in lavish descriptions of the characters but, interestingly, with the exception of Erna. Nałkowska failed to provide an extensive description of her appearance but decided to include exalted deliberations about art. She put them in a separate part of the novel: the protagonist's diary. It is worth noting here that Zofia was not the only sister to keep a diary. Young Hanna also recorded her memories, but this material has not survived. Some

\footnotetext{
${ }^{26}$ Leopold RYBARSKI, Z notatek o Zofii Natkowskiej, National Library, Special Collections, file: Hanna Kirchner-Materiały warsztatowe do Nałkowskiej, vol.1, call no. akc. 18554/1.

${ }^{27}$ The exact date is 17 May 1945.

${ }^{28}$ Halina M. DĄBRowolsKa, Portrety nieobiektywne. Wspomnienia o Zofii Natkowskiej (Wrocław: Zakład Narodowy im. Ossolińskich, 1958), man. 13924/II, 179. The manuscript was done in 1958; the book was never published.

${ }^{29}$ WACHNA, "Sposoby widzenia sztuki," 547.

${ }^{30}$ KIRCHNER, "Modernistyczna młodość," 86.
} 
references to her early diaries can be found in Hanna's later memoirs written after her mother's death in the $1940 \mathrm{~s}^{31}$

It is not obvious to what extent Ernestyna was fashioned after Hanna. Only a careful look at some individual facts from the life of both Nałkowski sisters can give some idea. Unfortunately, the details about the character and outlook of the younger sister are scarce and mostly come from Zofia's Dzienniki, so they are inherently subjective. According to the characters of Węże i róże, in her attitude to Marusia, Erna is "pretty, there is nothing to fault her. But she is not kind...she is inexorable, cold, only charming in her thoughts;" she copies "the easiness of her movements, a cheerful coldness of her smile and glance." ${ }^{32}$ Raissie, in turn, seems "always the same. It is terrible if someone is always the same." ${ }^{33}$ The researcher D. Wachna explained Erna's reserve, chill and irony towards others by the role that she has to fulfil. Her role was to offer a commentary on current events instead of being part of them. ${ }^{34}$ According to the narrator of Snakes and roses, "despite the assessment of various people, who succumb to her charm, Erna is not pretty. She has bushy black hair and is tall, that's all. But her facial features contain many irregularities, the face oval is elongated and bony. She is very pale and freckled. ...her complexion sometimes seems saturated with the light of a milky lamp shining with the dead transparency of minerals. Her eyes are small." ${ }^{35}$ This literary portrait can be easily confronted with the images of young Hanna Nałkowska. Let Susan Sontag's words, "photographs, which cannot themselves explain anything, are inexhaustible invitations to deduction, speculation, and fantasy," encourage further interpretation. ${ }^{36}$ Each photograph is only a fragment of the world that you do not know how to react to until you get to know it. ${ }^{37}$ Reception is determined on the context, which makes a photograph visually ambiguous. Looking at the photographs of young Hanna Nałkowska for the first time without knowing who she was, you

\footnotetext{
${ }^{31}$ Hanna NAŁKowsKa, Dziennik 1942-1945 (Warszawa: Biblioteka Narodowa), microfilm 110319.

${ }^{32}$ Zofia NaŁKOWSKA, Węże i róże, 109.

${ }^{33}$ Ibidem, 17.

${ }^{34}$ WACHNA, "Sposoby widzenia sztuki," 539, 547.

${ }^{35}$ Zofia NAŁKOWSKA, Węże i róże, 160.

${ }^{36}$ Susan SontAG, "W Platońskiej jaskini," in EADEM, O fotografii (Kraków: Karakter, 2010), 23.

${ }^{37}$ EADEM, "Heroizm widzenia," in ibidem, 86.
} 
can get the impression of certain permanence of the image, as in Raissa's description of Erna. We see a woman with a slim, pale face and absent look, usually gazing away from the camera lens (Imgs. 4, 5, 6, 7). Knowing that she is a young Warsaw sculptor, the sophisticated character of the image becomes apparent. Her absent and chilled look alludes to mystery, and her specific attire is explained by bohemia. The discussed photographs are not just ad hoc snapshots but the result of a self-staging session. In the defocused and foggy portraits with scarce details, we see Nałkowska posing and, thus, experiencing herself as a performance. ${ }^{38}$ In Węże i róże, Erna, too, uses actorly words and gestures. She seems to be a theatrical creation with a view to distinguishing her character against the background of the Oliwny family. Śniadowiczówna says, "You define yourself not only by your attitude to the world, but also by the world's attitude to you... You should be able to think about yourself as others do and look at yourself through other people's eyes." ${ }^{39}$ These words complement the analysis of Hanna Nałkowska's portraits very well. The researcher Kaja Silverman described this trick as "a photographic view of yourself." ages, the sculptor consciously turns into her own representation and offers the viewer a self-created image expecting them to accept it. ${ }^{41}$ At this point it is worth highlighting how different an image Zofia Nałkowska was creating for herself at that time. The writer placed her photographic performance against a staffage and filled it with numerous props (Imgs. 8, 9). Compared to Hann's rather uninhibited representations, Zofia's portraits are stiff and conventionbound. In their character they are reminiscent of the 19th-century "business cards" that Maria Poprzęcka described as, "a distant, democratized echo of a court representative portrait." 42 Their clarity and easiness of reception contradict the mystery and obfuscation of the sculptor's images. This kind of poetics adverts to the romantic female portraits taken by the photographer Julia Margaret

\footnotetext{
${ }^{38}$ Agata JAKUBOWSKA, Na marginesach lustra. Ciało kobiece $w$ pracach polskich artystek (Kraków: Universitas, 2004), 71.

${ }^{39}$ Zofia NAŁKOWSKA, Węże i róże, 184.

${ }^{40}$ Kaja Silverman, The Threshold of the Visible World (New York-London: Psychology Press, 1996), 197, quot. after: Agata JAKUBOWSKA, Na marginesach lustra, 71.

${ }^{41}$ Ibidem.

${ }^{42}$ Maria PoprzęCKA, "Szaleństwo babki Julii," in Virginia Woolf, Julia M. CAMERon, Maria POPRZĘCKA, Fakt, fikcja i fotografia albo co się zdarzyło we Freshwater, transl. by Magdalena Heydel (Kraków: Znak, 2013), 92.
} 
Cameron. ${ }^{43}$ Her models, despite make-up, pose naturally, have a dreamy look and avoid looking at the lens. Technical imperfections, i.e. lack of focus, lend Cameron's photographs a dreamy aura, close to the art of the Pre-Raphaelites inspired by the early Renaissance Italian painting. The influence of their art spread to the following generation of artists, and its reminiscences can be seen even in the photographic portrait convention used, for example, by the English sculptors Kathleen Scott Kennett ${ }^{44}$ and Clare Sheridan. ${ }^{45}$ Back then, the work of painters of the Pre-Raphaelite Brotherhood was all the rage across Europe,${ }^{46}$ in particular, the images of female models who aroused men's desires more than ever. ${ }^{47}$ In her Dziennik, Zofia Nałkowska wrote, "my beautiful sister, slim, pale like Rossetti's virgins; she bends over greenery above flower beds and plants flowers with a sullen face." 48 When studying Rossetti's paintings, Hanna's resemblance to Elizabeth Siddal cannot go unnoticed. It is not sure, however, whether Zofia's comparison concerned only beauty, or whether the writer had knowledge of the tragic life of the painter's wife and muse and, therefore, treated her sister as a complicated figure conflicted with the world. In Węze $i$ róże, Ernestyna used a similar comparison in her diary when recounting how she found a perfect model in Rome. She was "young, tall, pretty elegant, pale and sullen like Rosseti's virgins." 49 Hanna's characteristic beauty must have been frequently discussed among Zofia and friends of the Nałkowski family. When describing Hanna, Halina Dąbrowolska sees her as "fair, with a crown of grey hair and a small face like in Bourne Jones's paintings," ${ }^{50}$ while Karolina Beylin recalled a slender, grey-haired woman "with a subtle profile as if cut out

\footnotetext{
${ }^{43}$ Julia Margaret Cameron (1815-1879), an English amateur photographer.

${ }^{44}$ Kathleen Scott Kennet (1878-1947), an English sculptor, Auguste Rodin's student. Her husband was Robert Falcon Scott, an English navy captain and explorer of Antarctica.

${ }^{45}$ Clare Sheridan (1888-1970), an English sculptor and writer.

${ }^{46}$ Cf. Andrzej SzCZERSKI, Wzorce tożsamości: recepcja sztuki brytyjskiej w Europie Środkowej około 1900 roku (Kraków: Universitas, 2010). The fashion of the day did not spare Zofia Nałkowska. Her interests in the Victorian literature can be traced in her diary entries devoted to reading. In 1911 she wrote an article about Robert Browning, see Zofia NAŁKOwSKA, "Twórca dramatu 'introspektywnego.' Robert Browning," Świat 3 (1911): 5-6.

${ }^{47}$ Historia ciała, ed. Georges Vigarello (Gdańsk: słowo/obraz terytoria, 2011), 160.

${ }^{48}$ Zofia NAŁKowsKa, Dzienniki 1909-1917, 262 (entry dated 29.04.1913).

${ }^{49}$ EADEM, Węże i róże, 225.

${ }^{50}$ DąBrowolsKa, Portrety nieobiektywne, 2.
} 
from the paintings of the fashionable painter Bourne Jones." ${ }^{51}$ Erna might have resembled Hanna not only in her beauty but also in her passions. Raissa Benoni noted that the artist "keeps a real, live owl" in her studio. "...as you approach it, it gets three times bigger. And Ernestyna is at her best with her, feeds her with meat from her hand and strokes her on her horned head." ${ }^{52}$ While Zofia was writing Węże $i$ róże, the Nałkowskis kept an owl named Wunia in their house in Górki. Halina Maria Dąbrowolska remembered her as a sculptor's favourite pet. The owl was large, "fluffy like down.... She loved Hania and was kind to Zofia." 33

Another similarity between the sculptor and Erna is social activity. The protagonist of Węże $i$ róże gave free writing lessons to a young suburban girl who was a servant to a working-class family. In her diary, Ernestyna referred to the child as, "hungry for the light of knowledge." ${ }^{54}$ During the 1905-1907 revolution, Hanna Nałkowska offered tutoring to workers and peasants' children from Górki. 25 years later, she was awarded an honorary medal for her effort to save the Polish school. ${ }^{55}$ The sculptor would also teach geography in Warsaw and would give private drawing lessons ${ }^{56}$ It is worth noting that social activity was indisputably what made Hanna Nałkowska stand out. At that time, Zofia's ideology was totally confined to literary activity. ${ }^{57}$

The parts of the novel describing Erna's creative process can be likened to Hanna Nałkowska's working methods. Raissa Benoni described her tutor's technique as "struggle" because the artist would sit for hours, look at the model and break pieces of charcoal in her fingers. In the studio, she had a large number

\footnotetext{
${ }^{51}$ Karolina BEYLIN, "Domy kobiet," in Wspomnienia o Zofii Nałkowskiej (Warszawa: Czytelnik, 1965), 40.

${ }^{52}$ Zofia NAŁKOWSKa, Węże i róże, 60

${ }^{53}$ DĄBROWOLSKA, "Spojrzenie wstecz," in Wspomnienia, 108.

54 "When I dig tunnels and fix windows in the darkness of this childish brain, I am attracted to this beautiful expression that human development is manifested in the multiplication of automatic processes" (Zofia NAŁKOWSKA, Węże i róże, 209-210).

${ }^{55}$ Diploma of the Celebration Committee of the 25th Anniversary of Struggle for the Polish School, Personal Records of Hanna Nałkowska primo voto Bickowa, secundo voto Stefanowiczowa 1888-1970, National Library, Special Collections, call no. akc. 14101.

${ }^{56}$ Hanna NaŁKowsKa, Komentarze do Dzienników Zofii Nałkowskiej, National Library, Special Collections, call no. akc. 14104.

${ }^{57} 1907$ (8-11 June) is considered the end of Zofia Nałkowska's social activity (before the print of Węże i róże). In 1907 she took part in the National Women's Congress and delivered a speech, Views on Ethical Objectives of the Women's Movement.
} 
of started, yet unfinished works; she would work for three years on one portrait. ${ }^{58}$ When designing the character of Erna, Nałkowska made use of her observations of her sister. This is evidenced in the memories of Maria Wardasówna. She met both sisters after World War II and continued an amicable relationship with them and in the 1960s posed for a portrait made by Hanna (Img. 8). "Zofia firmly resisted her sister's persuasion to sculpture her head, claiming lack of time. She knew that Hania, unlike most sculptors, studied live models for weeks," Wardasówna wrote. ${ }^{59}$ Although we are talking about Zofia's portrait of the mid-1950s, Hanna's methods apparently had not evolved over time. The piece of Dziennik quoted above where Zofia talks about moistening sculptures, "I moisten and wrap her unfinished [author's emphasis-MK] sculptures with wet cloth to prevent them from drying and cracking," can be associated with a fragment of the novel in which Raissa reported a visit to Erna's studio full of unfinished works.

Ernestyna did not value talent, yet she recognized the vocation and creative resolve, which she admitted openly in the diary, "creativity based on the socalled 'talent,' that is, shady dealings that make friends with the form, is strange and indifferent to me. Creative desire is a drive to challenge things whose internal boundaries are the external boundaries of the realm of talent. The proper creativity comes where talent ends and struggle begins: lethal wrestling, grinding toil. And this is all about the form: man's will turning against mystery. $" 60$ The concept that claims that the act of creation is understood as work can be easily traced to the philosophy of Stanisław Brzozowski ${ }^{61}$ whom both sisters knew well in person. They were familiar with his writings, as we can see in Zofia's diary entries. ${ }^{62}$ Nałkowska treated him as an authority and outstanding intellectual, and she extremely valued his resolve and uncompromising nature of his philosophical quest. Leszek Kołakowski named Brzozowski eroico furioso

\footnotetext{
${ }^{58}$ Zofia NAŁKOWSKA, Węże i róże, 165.

${ }^{59}$ Maria WARDASÓwnA, Dzieła wybrane i Pamiętniki; Byla dla mnie objawieniem-wspomnienia $o$ ZN, typescript, National Library, Special Collections, file Hanna Kirchner. Materiały warsztatowe do Nałkowskiej, vol. 1, call no. akc. 18554/1.

${ }^{60}$ Zofia NAŁKOWSKA, Węże i róże, 161.

${ }^{61}$ Cf. Ewa Pieńkowska, Zofia Natkowska (Warszawa: Wydawnictwa Szkolne i Pedagogiczne WSiP, 1975), 30; KIELAK, Figury kryzysu, 381-383.

${ }^{62}$ Zofia NAŁKowsKa, Dzienniki 1899-1905 (Warszawa: Czytelnik, 1975), 80-81.
} 
who, with his every thought, wishes to embrace the whole universe, seeks global and immediate solutions, wants to get to the core with every move he makes, and has no time to toy with problems laboriously and timidly." 63 For Brzozowski, the concept of work meant an active attitude towards the world and treating work as a fundamental component of reality which makes it possible to understand life as a creative process: something that is being created all the time, and not provided in advance as ready-made. ${ }^{64}$ For the author of Ptomienie, only thought deserved equal relevance, but only if it could be put into action ${ }^{65}$ because "a thought with no relation to the hand is a mere illusion." ${ }^{66}$ It is worth noting that in his work Brzozowski devoted much space to sculpture and ranked it above all arts. ${ }^{67}$ In this context, the philosopher also reflects on the notion of work, "there is great wisdom in sculpture: you can rely only upon to what you can give the form of your life... What is not yourself in any way does not matter to you at all." ${ }^{68}$ Brzozowski's views are permeated with tragedy. The thinker identified human tragedy with a fulfilled person whose "life has fulfilled all his longing, all his ideals, where he has become drunk with himself." ${ }^{\circ 9}$ Erna expresses this idea in her diary, arguing for her abandonment of the art of painting as follows, "I have already passed through the world of colour and light, and now...I want to experience a new world of creative discoveries and astonishment. That is why I once gave up the violin for singing and later singing for drawing...I keep shedding my talent off and running away from the technique

${ }^{63}$ Leszek KoŁAKOwSKI, "Miejsce filozofowania Stanisława Brzozowskiego,” Twórczość 6 (1966), 43.

${ }^{64}$ Stefan KoŁACZKowsKi, "Praca-Prawo-Godność—Rola inteligencji-Dzieje. Fragmenty ze studiów o St. Brzozowskim,” in IDEM, Pisma wybrane, ed. Stanisław Pigoń (Kraków: Państwowy Instytut Wydawniczy, 1968), 191.

${ }^{65}$ For Brzozowski, work was, "1) a physical effort changing something in nature in accordance with our will; 2) a mental effort used for technical inventions and for maintaining the technique of social instruments; 3 ) a spiritual work creating such motives as to love life as the life of a working person must be" (ibidem, 192).

${ }^{66}$ Stanisław BrzozowsKI, Dzieła wszystkie, vol. IV (Warszawa: Wydawnictwo Instytutu Literackiego, 1936), 276.

${ }^{67}$ Cf. Stanisław Brzozowski, "Fryderyk Nietzsche," in IDEM, Kultura i życie (Warszawa: Księgarnia Polska B. Połonieckiego, 1973); Stanisław Brzozowski, "Styl Ibsena," in ibidem; Stanisław BrzozowsKI, "Etapy sentymentalizmu," in IDEM, Idee. Wstęp do filozofii dojrzałości dziejowej (Lwów: Wydawnictwo Literackie, 1910).

${ }^{68}$ BRzOZOWSKI, Idee, 429.

${ }^{69}$ IDEM, Kultura, 214. 
I have already mastered. I am looking for challenges that can get me closer to the real secret of beauty." ${ }^{70}$ For Ernestyna, the sense of fulfilment means a defeat that kills the desire of further search, "I keep shedding my talent off and running away from the technique I have already mastered. I am looking for challenges." ${ }^{71}$ In her words, "I desire a hard and undisputed shape. I desire sculpture that "so confidently cuts your beloved idea from the universe,",72 and again she agrees with Brzozowski's position for whom "painting and poetry open up infinite perspectives because there is more in them than mere presence and accomplishment; it is sculpture that says: I am what I am. Sculpture is the only art of finitude, it is the most human art. ...sculpture, the art of terrifying honesty, the art closing the entire tragedy, all its potentiality in a line, leaning; sculpture appealing to us with the language of the body shown as it is: a concrete form of our tragedy.... Statues are not made in marble or bronze, but in what is us, what appears to be our own shape." ${ }^{, 73}$ Erna keeps returning to the concept of form in her deliberations on creativity. It is worth noting that this concept was extremely close to Zofia as well. For her, the definition of form was closely linked to the way of thinking, writing and, above all, living. Already at the age of 18 she wrote, "Everything that happens to me I take literary-wise; I have a special form for receiving impressions, a special form for dreams and memories, and thoughts in general; an epic form, so to speak." ${ }^{74}$ That impeccable stylist, as Borkowska called her, maintained and safeguarded her forms throughout her life, regardless of the circumstances. ${ }^{75}$ That crucial importance of form in life must have been reflected on the pages of her novel. In Weże i róże, this attitude is exhibited in Erna's diary, "the life truth of interpersonal relations is

\footnotetext{
${ }^{70}$ Zofia NAŁKowsKa, Węże i róże, 166.

${ }^{71}$ Ibidem.

${ }^{72}$ Ibidem.

${ }^{73}$ BRZOZOWSKI, Idee, 427-328.

${ }^{74}$ Zofia NaŁKOWSKa, Dzienniki 1899-1905, 195.

${ }^{75}$ Grażyna BoRkowskA, "Płeć jako skaza: Przybyszewski i Nałkowska," in Nowa świadomość ptci w modernizmie. Studia spod znaku gender w kulturze polskiej i rosyjskiej u schyłku stulecia, ed. German Ritz, Christa Binswanger, Carmen Scheide (Kraków: Towarzystwo Autorów i Wydawców Prac Naukowych "Universitas," 2000), 93; cf. Alina KOCHAŃCZYK, "Kobiecość jako forma-przypadek Zofii Nałkowskiej," in Modernizm i feminizm: postacie kobiece w literaturze polskiej i obcej, ed. Eugenia Łoch (Lublin: Wydawnictwo UMCS, 2001), 195-204.
} 
their official side, their appearance, i.e. their form." "76 Nałkowska often employed this concept in Erna's reflections on creativity and the rules that govern it. It is worth noting that those reflections are not uniform across the diary and often reveal different and contradictory meanings. On the one hand, Erna says that form in art is "a value added to content," "77 on the other, she writes that "form is the highest content," ant and plunderer of content. Form is a curiosity and hatred not a robe. It is a hammer to smash secrets, it is a judgement and verdict." 79 As one of the researchers rightly points out, according to Erna's aesthetic code, creativity is a source of knowledge and sublime sensations. ${ }^{80}$ Her outlook permanently sides with the intellect; it is dispassionately rational and, therefore, devoid of "feeling." The diary of the protagonist of Węże i róże is a realm of contemplation of not only Erna-artist but also of Zofia Nałkowska for whom the power of thinking is stronger than the creative imperative. The author believes that "you can be an artist of knowledge, an aesthete of mathematics, an advocate of intellectual beauty." ${ }^{\prime 1}$ Her observations, though intricate and testifying to the author's unquestionable erudition, often approach platitude of Künstlerroman, so popular in the circles of the Young Poland literary movement. ${ }^{82}$ Erna's/Nałkowska's attitude towards creativity is primarily intellectual and is governed by the desire of empirical cognition, "to learn the mechanics of transposing invention into reality, to discover and explore the engineering of art forms: that is my dream. ${ }^{, 83} \mathrm{Na}$ kowska's analytical mind makes the protagonist concentrate only on the rational exploration of the principles that govern the making of a piece of art and strive

\footnotetext{
${ }^{76}$ Zofia NAŁKOWSKA, Węże i róże, 189.

${ }^{77}$ Ibidem, 162.

${ }^{78}$ Ibidem, 166

${ }^{79}$ Ibidem.

${ }^{80}$ WACHNA, "Sposoby widzenia sztuki," 549.

${ }^{81}$ Zofia NAlKowSKA, Węże i róże, 169.

${ }^{82}$ As early as in 1902, Kazimierz Irzykowski was critical about the activities of Young Poland artists, "That superstition was based on such an idée fixe that a work of art, as it was called, is designed in accordance with the principles of some unearthly, transcendent, mathematical and 'unwritten' aesthetics; that it is to constitute some strange symphony that must be altered in order not to destroy the unknown proportions of the work...a work of art is already written, perfect...the author's work consists in...writing down some cabbalistic whispering of spirits" (Karol IRZYKOWSKI, Patuba (Warszawa: Wydawnictwo Literackie, 1957), 120).

${ }^{83}$ Zofia NaŁKowsKa, Węże i róże, 166.
} 
to control its matter. In Węże i róże, there is no scene of Erna actually painting or sculpting. ${ }^{84}$ Unfortunately, Hanna Nałkowska's views on the problem of form, especially the sculptural form, are unknown. We can only presume that she was familiar with the fashionable or popular theories of the day. Assessment of an artwork based on the criteria defined as formal attributes was a consequence of the then prevailing trends in sculpture. Around 1910, the Polish sculpture experiences a regresses, mainly due to the powerlessness of artists who were unable to break free from the influences of Auguste Rodin's art. The impasse affected those artists who, based on Rodin's experience, were unable to find their own artistic path and were trapped in the closed circle of the French master's followers for ever. That blind and superficial travesty of Rodin's style, combined with the Young Poland fantasy of sculptors "dreaming about a masterpiece," led to formal neglect and composing "chewed lumps of breads." ${ }^{\circ 5}$ The crisis also bore upon sculpture in other countries. The concept of the sculptor and theoretician Adolf von Hildebrand helped tackle it. In 1893 he published Das Problem die Form in der bildenden Kunst. The book was so popular in Europe that it was reprinted in nine editions until $1914 .{ }^{86}$ Hildebrand in his theory demanded that a piece of work present a clearly defined idea that should be stripped of any understatements and random elements. For the design of a sculpture, it is important to distribute the masses evenly; at the same time, all spatial relations, including perspective shortcuts, should be so translated into the artistic language as not to obscure "the ability to read the form of being the specific object." ${ }^{87}$

An interesting issue, which Hanna Nałkowska and Erna seem to share, is the attitude towards the artistic profession. It should be assumed that the sculptor treated her profession and artistic passion as seriously as Ernestyna. The latter noted down in her diary, "Mr Czarostański is so audacious in his words that

\footnotetext{
${ }^{84}$ Erna's only finished work appeared early in the novel; it was a drawing portrait of Raissa made some time before, ibidem, 56-57.

${ }^{85}$ Rudolf WitTKOwer, Sculpture. Process and Principles (New York: Harper \& Row, 1977), 252.

${ }^{86}$ Piotr SzUBERT, "Glina - gips - marmur. O procesie twórczym dziewiętnastowiecznego rzeźbiarza," in Projekt-szkic_bozetto. Materiały seminarium metodologicznego Stowarzyszenia Historyków Sztuki, Nieborów, 22-24 czerwca 1989, ed. Maria Poprzęcka (Warszawa: Stowarzyszenie Historyków Sztuki, 1993), footnote 21.

${ }^{87}$ Wojciech Batus, "Wstęp," in Adolf von Hildebrand, Problem formy w sztukach plastycznych (Warszawa: Wydawnictwo UW, 2012), 11.
} 
today he has officially asked me if I marry him. I said that I could not do it because I am too busy with my art." ${ }^{\prime 88}$ Until the 1920 s, Zofia had only once mentioned her sister's sweetheart in her diary. In 1906 the writer and her husband left for Kielce where he took the position of literary director of the Echo Kieleckie daily. One of the publishers was Jakub Wołczek, a progressive Russian teacher expelled from a Polish school after a strike. ${ }^{89}$ Shortly afterwards, Wołczek moved to Warsaw and began teaching at a finishing school and the male junior high school of Emilian Konopczyński. ${ }^{90} \mathrm{He}$ probably met Hanna through Zofia's husband around 1907. In her memories, Dąbrowolska called him "the musician Wilczek-Wołczek, Hanna's admirer."91 They engaged in a long relationship which lasted until March 1913 when, as Zofia put it, the "incurable engagement" was broken. ${ }^{92}$ It is worth noting that during that period the writer worked assiduously on Węże $i$ róże. Why their relationship failed is not known, but, according to Zofia, Hanna accepted the end of the relationship as "simple liberation." ${ }^{93}$ Significantly, as already mentioned, two months after this event, Hanna exhibited her works at the Zachęta Salon for the first time. Half a year later, she showed two more sets of her pieces at the local Annual Salon. ${ }^{94}$ From then on, the sculptor was increasingly active as an artist, and a year and a half later she resumed her interrupted studies at the Warsaw School of Fine Arts. The broken engagement proved beneficial: it can be assumed that the affair had inhibited the artist's creative aspirations. ${ }^{95}$ At this point, it is worth referring to the concept of the New Woman by Elaine Showalter. ${ }^{96}$ Hanna Na1kowska embodied an independent woman, trying to find fulfilment as an artist

${ }^{88}$ Zofia NAŁKOWSKA, Węże i róże, 211.

${ }^{89}$ DĄBROWOLSKA, Portrety nieobiektywne, 34.

${ }^{90}$ Zofia NaŁKowska, Dzienniki 1909-1917, 77.

${ }^{91}$ Halina M. DĄBRowolsKa, Wspomnienie, National Library, Special Collections, file: Hanna Kirchner-Materiały warsztatowe do N., vol. 4, call no. akc. 18554/4.

${ }^{92}$ Zofia NaŁKowSKa, Dzienniki 1909-1917, 252.

${ }^{93}$ Letter written by Zofia Nałkowska to her friend Zofia Villaume, dated 16.03.1913, see ibidem, $251-252$.

${ }^{94}$ Cf. note 14 .

${ }^{95}$ Cf. Maria PoprzęCKA, "Czy artystce wolno wyjść za mąż," in Pochwała malarstwa. Studia $z$ historii i teorii sztuki (Gdańsk: słowo/obraz terytoria, 2000), 208-216.

${ }^{96}$ Daughters of Decadence: Women Writers of the Fin-de-Siècle, ed. Elaine Showalter, (New Brunswick: Rutgers University Press, 1993). 
and, as seen in her relationship with Wołczek, not afraid of seeking self-actualization in the erotic sphere, too. ${ }^{97}$ She got married as late as in 1924 to a civil servant, Maksymilian Bick, whom she had known for some time. As a discerning beholder of human types and characters, Zofia Nałkowska reliazed how important sculpture was for Hanna. In the 1920s Dziennik, she noted, "I went to Warsaw again for Hanka's wedding; she has finally chosen the husband. Well, she did not betray art through marriage because her husband offered her the same support and complete understanding as the mother had." 98

The figure of Ernestyna is not a one-to-one embodiment of Hanna Nałkowska, yet she shares some traits with the sculptor. Zofia certainly did not want to convey a loyal image of her sister; instead, she equipped her protagonist with some of Hanna's essential qualities. The rest of Erna's personality Nałkowska "appended" at her own discretion, which explains the artist's lofty remarks about art, beauty, or people. In fact, the writer rarely tackled the problem of art in her literary output. According to Wanda Melcer, "in the field of plastic arts," Nałkowska "was somewhat in the dark but, thanks to her unerring instinct, she let herself to be guided by the opinions of people whom she trusted on this matter." "99 On the other hand, based on the account of Tymon Terlecki, who accompanied Zofia Nałkowska in Paris in the 1930s, the writer's "perception of plastic works was rather literature-driven and seemed not to have gone beyond impressionism and post-impressionism," although she was quite sensitive and receptive when it came to visual arts. "If something moved her and she phrase her feelings into a satisfying wording, she immediately wrote it down." ${ }^{100}$ This literariness can be easily seen already in Węże i róże, where art is discussed only in generic terms and not without a sense of sublimity. ${ }^{101}$ In this way, Zofia

\footnotetext{
${ }^{97}$ Cf. Elaine Showalter, Sexual Anarchy (London: Viking, 1996), 40, after Aneta Górnicka-Boratyńska, "Śliczna moja siostra natura. Projekt 'Nowej Kobiety' w modernistycznej twórczości Zofii Nałkowskiej," in EADEM, Stańmy się sobq. Cztery projekty emancypacji (1863-1939) (Warszawa: Czarna Owca, 2001).

${ }^{98}$ Zofia NaŁKOWSKa, Dzienniki 1918-1929 (Warszawa: Czytelnik, 1989), 111 (entry dated 04.06.1924).

${ }^{99}$ Wanda Melcer, “Kolor przeszłości,” in Wspomnienia o Zofii Nałkowskiej, 248.

${ }^{100}$ Tymon Terlecki, "Notatki o Zofii Nałkowskiej," in Zofia NAŁKowsKA, Dzienniki, vol. IV, part 1 (Warszawa: Czytelnik, 1988), 371.

${ }^{101}$ Cf. Z problemów prozy. Powieść o artyście, ed. Wojciech Gutowski, Ewa Owczarz (Torun: Wydawnictwo Adam Marszałek, 2006); Waldemar OKOŃ, "Figury i chimery. Rzecz o kilku utworach
} 
Nałkowska reproduced one of the simplified frameworks found in most Polish "novels about artists" depicting passion, theorizing, powerlessness or creative power, but with no work ever created. ${ }^{102}$ The secondary artistic thread seemed outmoded: its climax came at the end of the $19^{\text {th }}$ century and in the $1910 \mathrm{~s} .{ }^{103}$ The contemporary Künstlerroman abounded in books on male sculptors; yet, the stories of female sculptors were rare. ${ }^{104}$ Perhaps that is why Nałkowska decided to explore the idea, although she failed to do it in full. The researcher Dorota Kielak, in a book devoted to sculptural threads in the Young Poland novel about artists, pointed out that Zofia Nałkowska had grasped the concept of this area of visual arts thanks to her sister and her "fascinations." 105 The writer showed Ernestyna in an artistic void and never spoke about her status in artistic circles nor about her financial standing, although she seems financially independent. In this way, Nałkowska again copied a concept exploited in books about artists. For this genre of literature was always very conservative about providing infor-

prozą i jednym wykładzie," Rzeźba Polska 8 (1996-1997), 181-188, and also Andrzej Z. MAKOWIECKI, Mtodopolski portret artysty (Warszawa: Państwowy Instytut Wydawniczy, 1971); Piotr SzUBERT, Rzeźba polska przełomu XIX i XX wieku (Warszawa: Wydawnictwo Naukowe Semper, 1995).

${ }^{102}$ Cf. Henryk SienKIEWICZ, Lux in tenebris lucet, first print in Biblioteka Warszawska 1891, vol. 1, 1-8; Tadeusz JaroszyŃski, Chimera. Powieść z przedmowa Zdzisława Dębickiego, [b.w.] (Warszawa: Drukarnia Józefa Sikorskiego, 1905); Kazimierz PRZERWA-TETMAJER, Aniot śmierci. Romans (Warszawa: Universitas, 1989); IDEM, Zatracenie. Romans (Warszawa: Księgarnia Wiedza i Sztuka Sz. Taffeta, 1905).

${ }^{103}$ Cf. ibidem.

${ }^{104}$ It is worth noting that the turn of the 19th century saw the growing importance of sculpture, mainly thanks to Auguste Rodin whose work contributed to the greater independence of this field of arts. The story of the sculptor Camille Claudel, the master's muse and assistant, proves how difficult it was for women to elbow their way into this profession. The main obstacle was limited access to higher education. In partitioned Poland, female artists had an easier way to go because the Warsaw School of Fine Arts started to admit women from the very beginning of its operation, i.e. from 1904.

In the Polish literature of the time, the figures of female artists are rare, and, interestingly, if a female artist did appear, she would usually be a painter not a sculptor. In most cases, they play a supporting role, and their artistic talent does not determine the course of events, as is the case with the sculptor Bronka from Maria Rodziewiczówna’s 1887 Straszny Dziadunio. A she-sculptor appears in Gość kamienny by Antoni Sygietyński as a master's student. Sygietyński published the novel in parts in the Sfinks magazine parallel to Nałkowska's Węże i róże (April, May and June issues); the typescript was written earlier in early 1912 and is now available in the Ossolineum Library in Wrocław. Antoni SYGIETYŃSKI, Gość kamienny, [short story], ref. 13211/I.

${ }^{105}$ KIELAK, Figury kryzysu, 37. 
mation on artist's social environment and occupation. ${ }^{106}$ It is hard not to receive the impression that today the figure of Erna-artist might be exposed to lampooning. She did not create anything throughout the novel but was merely theorizing and making herself into an artist. Certainly, to some extent, Nałkowska's choices were driven by the idea to create a picture of an ideal Young Poland artist, combining intellectual and creative attributes. The key quote that clarifies the title of the novel is also a symbolic reference to the Nałkowski sisters that brings together Zofia's reason and Hanna's nature. The writer argues that the two forces can be harmonized, "The other day, when reading the description of ceiling paintings in a palace in Forli, I noticed a symbol that seemed somewhat accidental: there was an image of coats of arms of two Italian families: the serpents of the Sforzas and the roses of the Riarios. Węże $i$ róże is a symbol of reconciliation, covenant and alliance of two powers of the human spirit fighting an eternal war: the power of reason and the power of the spirit.",107

List of images

1. Hanna Nałkowska, Helenka, 1913, plaster; repr. after: Salon Wiosenny artystów warszawskich: maj-czerwiec 1913 (Warszawa: Towarzystwo Zachęty Sztuk Pięknych, 1913).

2. Hanna Nałkowska, Portrait of Zofia Natkowska, 1913, plaster; repr. after Świat 1(1914), 14.

3. Hanna Nałkowska, Portrait of Mrs. Z.G., 1913, plaster; repr. after Świat 1(1914), 14.

4. Portrait of Hanna Nałkowska before 1915; repr. after the National Library, Special Collections, Photographs by Hanna Stefanowiczowa née Nałkowska, call no. akc. 14110

5. Portrait of Hanna Nałkowska before 1915; repr. after the Museum of Literature, From the Collection of Hanna Kirchner, call no. akc. I 7086.

6. Portrait of Hanna Nałkowska before 1915; repr. after the National Library, Special Collections, Photographs by Hanna Stefanowiczowa née Nałkowska, call no. akc. 14110

7. Portrait of Hanna Nałkowska before 1915; repr. after the Museum of Literature, From the Collection of Hanna Kirchner, call no. akc. I 7086.

8. Portrait of Zofia Nałkowska ca. 1910; repr. after Zofia Nałkowska, Dzienniki 1909-1917 (Warszawa: Czytelnik, 1976), 128-129.

9. Portrait of Zofia Nałkowska before 1914; repr. after Zofia Nałkowska, Dzienniki 1909-1917 (Warszawa: Czytelnik, 1976), 208-209.

10. Hanna Nałkowska, Portrait of Zofia Natkowska, 1954, plaster; the National Library, Special Collections, Photographs by Hanna Stefanowiczowa née Nałkowska, call no. akc. 14111

\footnotetext{
${ }^{106}$ MAKOWIECKI, Młodopolski portret, 47.

${ }^{107}$ Zofia NAŁKOWSKA, Węże i róże, 213.
} 


\section{BIBLIOGRAPHY}

BEyLIN, Karolina. “Domy kobiet.” In Wspomnienia o Zofii Natkowskiej. Warszawa: Czytelnik, 1965.

BorkowsKA, Grażyna. Cudzoziemki. Studia o polskiej prozie kobiecej. Warszawa: Instytut Badań Literackich PAN, 1996.

BORKOwSKA, Grażyna. "Płeć jako skaza: Przybyszewski i Nałkowska." In Nowa świadomość płci $w$ modernizmie. Studia spod znaku gender $w$ kulturze polskiej i rosyjskiej u schyłku stulecia, ed. German Ritz, Christa Binswanger, Carmen Scheide. Kraków: Towarzystwo Autorów i Wydawców Prac Naukowych "Universitas," 2000.

Brzozowski, Stanisław. Idee. Wstęp do filozofii dojrzałości dziejowej. Lwów: Wydawnictwo Literackie, 1910.

BrzozowsKi Stanisław. Dzieła wszystkie. Vol. IV. Warszawa: Wydawnictwo Instytutu Literackiego, 1936.

BrzozowsKi, Stanisław. Kultura i życie. Warszawa: Księgarnia Polska B. Połonieckiego, 1973.

Daughters of Decadence: Women Writers of the Fin-de-Siècle, ed. Elaine Showalter. New Brunswick: Rutgers University Press, 1993.

DĄBRowolsKa, Halina M. "Spojrzenie wstecz.” In Wspomnienia o Zofii Nałkowskiej. Warszawa: Czytelnik, 1965.

GóRnICKA-BoratyŃSKA, Aneta. Stańmy się soba. Cztery projekty emancypacji (1863-1939). Warszawa: Czarna Owca, 2001.

HILDEBRAND VON, Adolf. Problem formy w sztukach plastycznych. Warszawa: Wydawnictwo Uniwersytetu Warszawskiego, 2012.

Historia ciała, ed. Georges Vigarello. Vol. I-III. Gdańsk: słowo/obraz terytoria, 2011-2014.

IRZYKowsKi, Kazimierz. Pałuba. Warszawa: Czytelnik, 1957.

JAKUBOWSKA, Agata. Na marginesach lustra. Ciało kobiece $w$ pracach polskich artystek. Kraków: Universitas, 2004

JAROSZYŃSKI, Tadeusz. Chimera. Powieść z przedmowa Zdzisława Dębickiego. Warszawa: Drukarnia Józefa Sikorskiego, 1905

KASA, Magdalena. “'Rzeźbię, co koń wyskoczy.' O twórczości Hanny Nałkowskiej.” Aspiracje 3 (2015).

KIELAK, Dorota. Figury kryzysu. Rzeźba w młodopolskiej powieści o artyście. Warszawa: Wydawnictwo UKSW, 2007.

KIRCHNER, Hanna. "Modernistyczna młodość Zofii Nałkowskiej.” Pamiętnik Literacki 1 (1968).

KIRCHNER, Hanna. Natkowska albo życie pisane. Warszawa: Wydawnictwo W.A.B., 2011.

KochAŃCZYK, Alina. "Kobiecość jako forma-przypadek Zofii Nałkowskiej.” In Modernizm i feminizm: postacie kobiece w literaturze polskiej $i$ obcej, ed. Eugenia Łoch. Lublin: Wydawnictwo UMCS, 2001.

KoŁaczKowski, Stefan. Pisma wybrane, ed. Stanisław Pigoń. Kraków: Państwowy Instytut Wydawniczy, 1968

KoŁAKOWSKI, Leszek. “Miejsce filozofowania Stanisława Brzozowskiego.” Twórczość 6 (1966). 
MAKOWIECKI, Andrzej Z. Młodopolski portret artysty. Warszawa: Państwowy Instytut Wydawniczy, 1971.

Melcer, Wanda. "Kolor przeszłości.” In Wspomnienia o Zofii Nałkowskiej. Warszawa: Czytelnik, 1965.

NAŁKOWSKA, Zofia. “Twórca dramatu ‘introspektywnego.’ Robert Browning.” Świat 3 (1911).

NaŁKowsKa, Zofia. Dzienniki 1899-1905. Warszawa: Czytelnik, 1975.

NAŁKowSKa, Zofia. Dzienniki 1909-1917. Warszawa: Czytelnik, 1976.

NAŁKowsKa, Zofia. Węże i róże. Warszawa: Czytelnik, 1977.

NaŁKowsKa, Zofia. Dzienniki 1918-1929. Warszawa: Czytelnik, 1989.

NAŁKOWSKA, Zofia. Dzienniki 1939-1944. Warszawa: Czytelnik, 1996.

OKoŃ, Waldemar. "Figury i chimery. Rzecz o kilku utworach prozą i jednym wykładzie." Rzeźba Polska 8 (1996-1997).

PIEŃKOwSKA, Ewa. Zofia Nałkowska. Warszawa: Wydawnictwa Szkolne i Pedagogiczne WSiP, 1975.

POPRZĘCKA, Maria. "Czy artystce wolno wyjść za mąż." In EADEM, Pochwała malarstwa. Studia $z$ historii i teorii sztuki. Gdańsk: słowo/obraz terytoria, 2000.

PoprzęCKA, Maria. "Szaleństwo babki Julii." In Virginia Woolf, Julia M. CAMERon, Maria PoPRZĘCKA, Fakt, fikcja i fotografia albo co się zdarzyto we Freshwater. Translated by Magdalena Heydel. Kraków: Znak, 2013.

Przerwa-TetMajer, Kazimierz. Aniot śmierci. Romans. Warszawa: Universitas, 1989.

Przerwa-Tetmajer, Kazimierz. Zatracenie. Romans. Warszawa: Księgarnia Wiedza i Sztuka Sz. Taffeta, 1905.

RembowsKA-PŁÓCIENNIK, Magdalena. "Family Nausea: Attitudes towards Family Values in Zofia Nałkowska's 'Snakes and Roses' and 'The Impatient Ones."' In Gender and Sexuality in Ethical Context, ed. Ursula Phillips, Knut A. Grimstad. Bergen: University of Bergen, 2005.

Rodziewiczówna, Maria. Straszny Dziadunio. Warszawa: Świat Książki, 1898.

SHOwALter, Elaine. Sexual Anarchy. London: Viking, 1996.

SiENKIEWICZ, Henryk. Lux in tenebris lucet. First print in Biblioteka Warszawska 1891. Vol. 1.

Silverman, Kaja. The Threshold of the Visible World. Nowy York-Londyn Psychology Press, 1996.

SonTAG, Susan. O fotografii. Kraków: Karakter, 2010.

SzCZERSKI, Andrzej. Wzorce tożsamości: recepcja sztuki brytyjskiej w Europie Środkowej około 1900 roku. Kraków: Universitas, 2010.

SzUBERT, Piotr. "Glina-gips-marmur. O procesie twórczym dziewiętnastowiecznego rzeźbiarza." In Projekt-szkic-bozetto. Materialy seminarium metodologicznego Stowarzyszenia Historyków Sztuki, Nieborów, 22-24 czerwca 1989, ed. Maria Poprzęcka. Warszawa: Stowarzyszenie Historyków Sztuki, 1993.

SzUBERT, Piotr. Rzeźba polska przełomu XIX i XX wieku. Warszawa: Wydawnictwo Naukowe Semper, 1995 
TerleCKI, Tymon. "Notatki o Zofii Nałkowskiej.” In Zofia Nałkowska, Dzienniki. Vol. IV. Part 1. Warszawa: Czytelnik, 1988.

Toмczok (Cuber), Marta. "Krew i dymy holokaustów. "Węże i róże” wobec kwestii żydowskiej w twórczości Zofii Nałkowskiej." In Granice Zofii Natkowskiej, ed. Agata Zawiszewska, 265284. Warszawa Uniwersytet Szczeciński, 2014.

Towarzystwo Zachęty Sztuk Pięknych w Królestwie Polskim. Salon 1913. Grudzień-styczeń. Warszawa: Zakł. Graf. B. Wierzbicki i S-ka, 1913.

Towarzystwo Zachęty Sztuk Pięknych w Królestwie Polskim. Salon Wiosenny artystów warszawskich: maj-czerwiec 1913. Warszawa: Zakł. Graf. B. Wierzbicki i S-ka, 1913.

UMIŃSKA, Bożena. “Zofia Nałkowska, 'Węże i róże.' Odmieniec.” In EADEM, Postać z cieniem. Portrety Żydówek w polskiej literaturze od połowy XIX wieku do 1939 roku. Warszawa: Sic!, 2011.

WACHNA, Dagmara. "Sposoby widzenia sztuki w 'Wężach i różach' Zofii Nałkowskiej oraz 'Przygodzie w nieznanym kraju’ Anieli Gruszeckiej.” Ruch Literacki 5 (2001).

WittKower, Rudolf. Sculpture. Process and Principles. New York: Harper \& Row, 1977.

WóJcıK, Włodzimierz. Zofia Nałkowska. Warszawa: Wiedza Powszechna, 1973.

Z problemów prozy. Powieść o artyście, ed. Wojciech Gutowski, Ewa Owczarz. Toruń: Wydawnictwo Adam Marszałek, 2006.

\section{ARCHIVAL MATERIAL}

\section{WARSZAWA}

DĄBROWOLSKA Halina Maria. Wspomnienie, Biblioteka Narodowa w Warszawie, Zbiory Specjalne, Hanna Kirchner-Materiały warsztatowe do N., t. 4, akc. 18554/4.

Dokumenty osobiste Hanny Nałkowskiej 1 voto Bickowej 2 voto Stefanowiczowej 1888-1970, Biblioteka Narodowa w Warszawie, Zbiory Specjalne, akc. 14101.

NAŁKOWSKA Hanna. Dziennik 1942-1945, Biblioteka Narodowa, Warszawa, mf 110319.

NAŁKOwSKa Hanna. Komentarze do "Dzienników" Zofii Nałkowskiej, Biblioteka Narodowa, Zbiory Specjalne, akc. 14104.

RYBARSKI Leopold. Z notatek o Zofii Nałkowskiej, Biblioteka Narodowa w Warszawie, Zbiory Specjalne, teczka Hanna Kirchner-Materiały warsztatowe do Nałkowskiej, t. 1, akc. 18554/1.

WARDASÓwna Maria. Dzieła wybrane i Pamiętniki; Była dla mnie objawieniem-wspomnienia o ZN, Biblioteka Narodowa, Zbiory Specjalne, teczka Hanna Kirchner. Materiały warsztatowe do Nałkowskiej, t. 1, akc. 18554/1.

WROCŁAW

DĄBROWOLSKA Halina Maria. Portrety nieobiektywne. Wspomnienia o Zofii Nałkowskiej, Zakład Narodowy im. Ossolińskich we Wrocławiu, rkps 13924/II [1958].

SYGIETYŃSKI Antoni. Gość kamienny. Nowela, Biblioteka Ossolineum we Wrocławiu, sygn. 13211/I (1912). 


\section{TWO SISTERS: THE SCULPTOR HANNA NAŁKOWSKA IN THE LIGHT OF ZOFIA NAŁKOWSKA'S NOVEL WĘŻE I RÓŻE}

The article focuses on Ernestyna Śniadowiczówna, the main character in a novel by Zofia Nałkowska, Węże i róże [Snakes and Roses] (1913). The main purpose of the work is to show that the character had its real counterpart in Zofia's younger sister, the sculptor Hanna Nałkowska. The words of Zofia herself were crucial, who in her Diary confessed that all her novels were autobiographical to some extent. Still, researchers have not paid sufficient attention to the significant similarities between Ernestyna and Hanna Nałkowska. Węże $i$ róże is the only piece in the writer's output in which she analyzed the issues related to art and pointed out some characteristics of the artist. Zofia was writing her novel when Hanna was entering the world of art. A comparison between Ernestyna Śniadowiczówna and Hanna Nałkowska, as well as the information from Zofia's Dziennik and reminiscences of their friends show that the literary character is likely to be based on a real person.

Key words: Zofia Nałkowska; Hanna Nałkowska; Polish sculptors; Węże i róże; plastic arts; literature; novel about artist.

Translated by Konrad Szulga

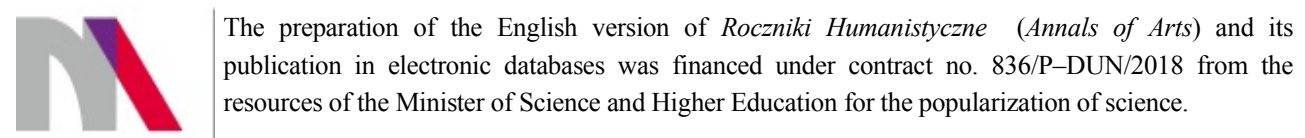

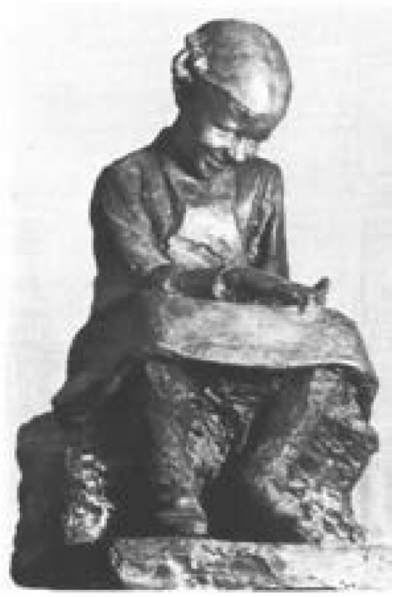

1. Hanna Nałkowska, Helenka, 1913, plaster; repr. after: Salon Wiosenny artystów warszawskich: maj-czerwiec 1913 (Warszawa: Towarzystwo Zachęty Sztuk Pięknych, 1913)

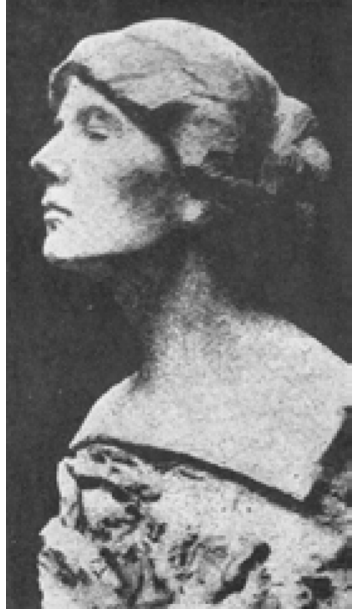

2. Hanna Nałkowska, Portrait of Zofia Nałkowska, 1913, plaster; repr. after Świat 1(1914), 14 


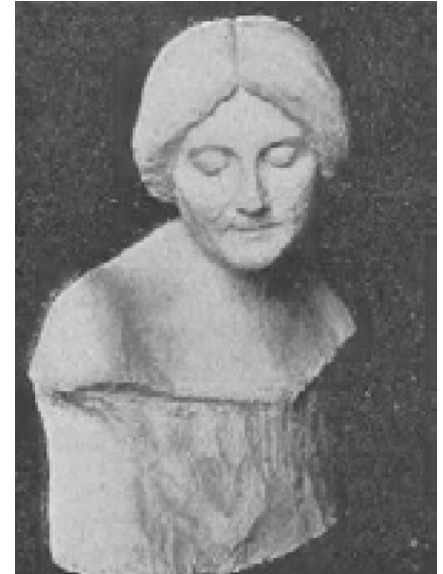

3. Hanna Nałkowska, Portrait of Mrs. Z.G., 1913, plaster; repr. after Świat 1(1914), 14

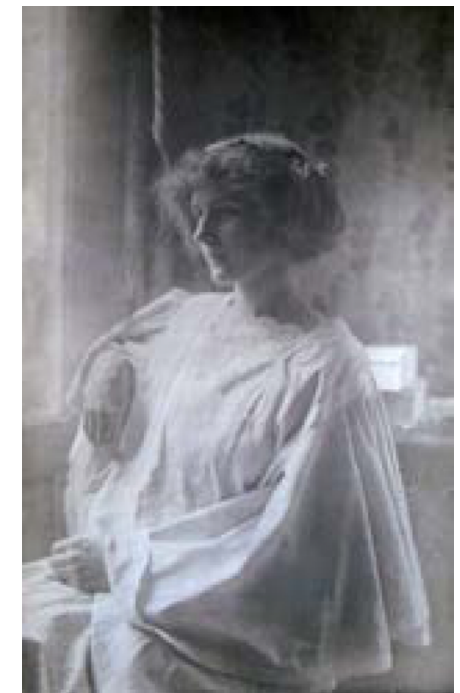

4. Portrait of Hanna Nałkowska before 1915; repr. after the National Library, Special Collections, Photographs by Hanna Stefanowiczowa née Nałkowska, call no. akc. 14110

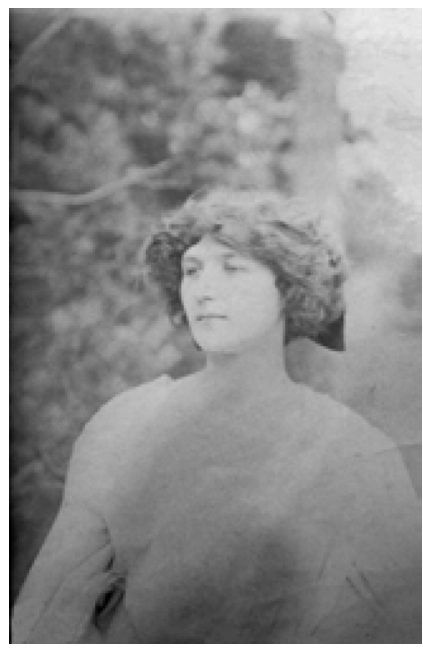

5. Portrait of Hanna Nałkowska before 1915; repr. after the Museum of Literature, From the Collection of Hanna Kirchner, call no. akc. I 7086 


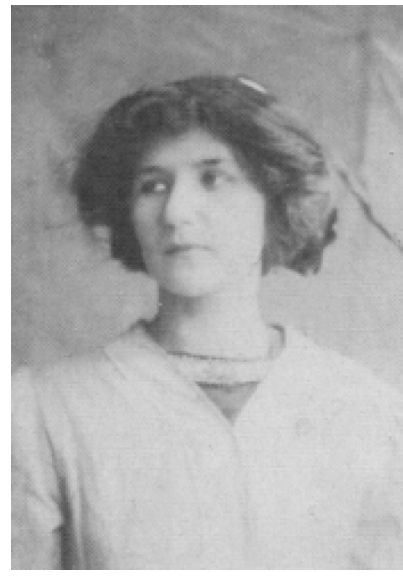

6. Portrait of

Hanna

Nałkowska

before 1915;

repr. after the

National Library,

Special

Collections,

Photographs by

Hanna Stefano-

wiczowa née

Nałkowska, cal

no. akc. 14110

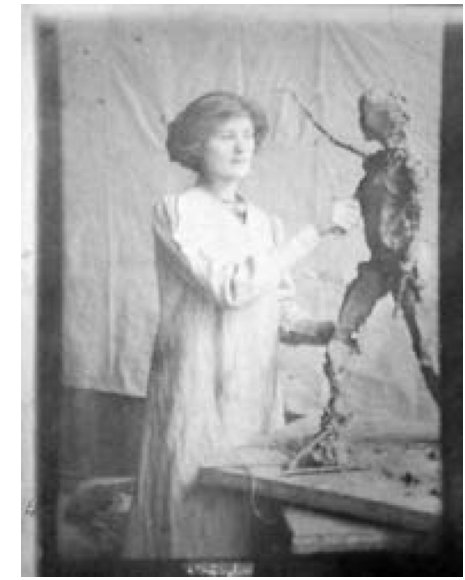

7. Portrait of

Hanna

Nałkowska

before 1915;

repr. after

the Museum

of Literature,

From the

Collection of

Hanna

Kirchner,

call no. akc.

I 7086
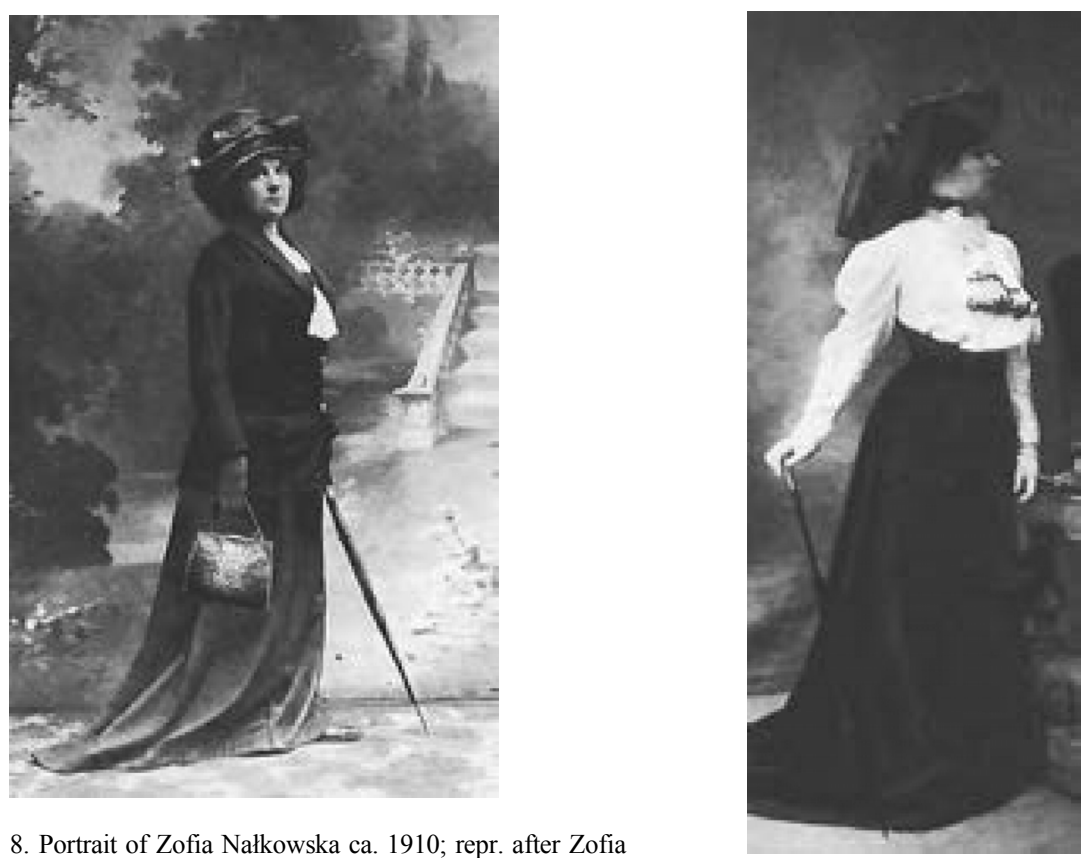

9. Portrait of

Zofia Nałkow-

ska before

1914; repr.

after Zofia

Nałkowska,

Dzienniki

1909-1917

(Warszawa:

Czytelnik,

1976), 208-

8. Portrait of Zofia Nałkowska ca. 1910; repr. after Zofia 209

Nałkowska, Dzienniki 1909-1917 (Warszawa: Czytelnik, 1976), 128-129 


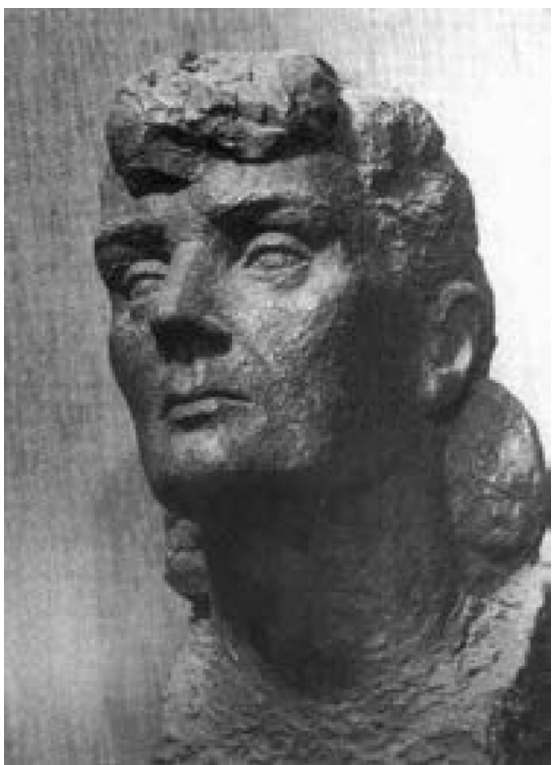

10. Hanna Nałkowska, Portrait of Zofia Natkowska, 1954, plaster; the National Library, Special Collections, Photographs by Hanna Stefanowiczowa née Nałkowska, call no. akc. 14111 